\title{
A Long Term Study on the Health Status and Performance of Sows on Different Feed Allowances during Late Pregnancy
}

\section{Clinical observations, with special reference to agalactia post partum}

\author{
By Arne Persson, Anne Eide Pedersen, Lelf Göransson and Wladyslaw Kuhl. \\ Department of Obstetrics and Gynaecology, Department of Veterınary Microbılogy and \\ Department of Anımal Nutrition and Management, \\ Swedish University of Agricultural Sciences, Uppsala, Sweden.
}

\begin{abstract}
Persson, A., A. E. Pedersen, L. Göransson and W. Kuhl: A long term study on the health status and performance of sows on different feed allowances during late pregnancy. I. Clinical observations, with special reference to agalactia post partum. Acta vet. scand. 1989, 30, 9-17. - Thirty nine pairs of full sibs were investigated over 6 parities in a long term study on the effects of late pregnancy feed allowance on the occurrence of agalactia post partum and on the performance of sows and piglets. A careful examination of all sows with a rectal temperature exceeding $39.5^{\circ} \mathrm{C}$ was performed by a veterinarian within the first $48 \mathrm{~h}$ after farrowing. Milksamples were taken from sows with elevated rectal temperatures and showing cl1nical symptoms of agalactia. During the last 15 days of gestation the sows in the control group were fed $3.4 \mathrm{~kg}$ daily and the sows in the experimental group $1.0 \mathrm{~kg}$ daily of a commercial type of diet. In $26.6 \%$ of the farrowings in the control group the sows were agalactic whereas the corresponding figure in the experimental group was $14.4 \%$.

On clinical examination udder changes were observed in a majority of the diseased sows in both groups. However, the agalactic sows in the control group were generally more affected, with lower water and feed consumption than in the experimental group. No effects of age of the sow (parity number) or length of the gestation period on the incidence of agalactia were demonstrated. The rectal temperature of agalactic sows was significantly higher than in the healthy sows already 1 day before farrowing. The agalactic sows farrowed a larger number of stillborn piglets, which indicates an early establishment of the disease. The number of weaned piglets at 6 weeks did not differ between agalactic and healthy animals. The interval from weaning to first oestrus was not influenced by agalactia in the preceding lactation.
\end{abstract}

Agalactia post partum; late pregnancy feeding; clinical signs; parity number; length of gestation period; litter sıze; oestrus interval; causes for culling.

\section{Introduction}

Agalactia post partum is a disease syndrome frequently diagnosed in the sow at farrowing, or within the first $48 \mathrm{~h}$ after parturition (Hermansson et al. 1978). The range of incidence in Swedish herds has been reported from $5.5 \%$ in small herds to $10.3 \%$ in large herds (Bäckström 1973). More recent figures from Denmark reveal an incidence of $9.5 \%$, independent of herd size, calculated from a total of 80,000 farrowings (Jorsal 1983).

The main clinical symptoms in diseased 
sows often originate from the mammary gland resulting in hypogalactia or agalactia. Enlargement and discoloration of one or more mammary glands and reluctance to allow nursing are common findings in agalactic animals. Pathological and microbiological findings at necropsy have indicated that mastitis associated with isolation of Escherichla coll is an important component of the disease (Rıngarp 1960, Ross et al 1975, Middleton-Willams et al. 1977, Ross et al. 1981). Affected sows also often show an elevated rectal temperature and inappetence (Rıngarp 1960, Hermansson et al 1978). Mortality is usually low but considerable losses are seen due to starvation and insufficient colostrum intake in the offspring (Jorsal 1983). The treatment of agalactic sows usually includes oxytocin to reestablish the milk flow as quickly as possible, antibiotıcs and corticosteroids (Elmore \& Martin 1986).

The etiology of the agalactia syndrome appearing within $48 \mathrm{~h}$ after parturition is still unknown although many causes, such as hormonal dysfunctions, stress, mycotoxins and bacterial infections, have been suggested in the literature (Ross et al. 1975, Ross et al. 1981, Elmore \& Martın 1986).

In some herds a prolonged gestation period has been reported to precede agalactia (Rıngarp 1960). In recent investigations however, no differences in length of gestation periods have been shown between healthy and agalactic sows (Hermansson et al. 1978, Jorsal 1983).

Partus induction using prostaglandins (PG $\mathrm{F}_{2}$ alpha) in herds with a high incidence of agalactia has been shown to reduce the frequency of clinical agalactia (Einarsson et al. 1975, Bäckström et al 1976).

The work of Ringarp (1960) and field studies by Sandstedt et al. (1979) have drawn attention to the influence of feeding intensity during late pregnancy on agalactia in the sow. In one of the field studies carried out by Sandstedt \& Sjögren (1982), the occurrence of agalactia was significantly reduced after a substantial restriction of the daily feed allowance together with increased access to hay or straw during the last 3 weeks of gestation.

With reference to these results a research programme to study the effects of very restricted late pregnancy feeding on health status and performance was designed. The results from this research programe will be presented in a series of papers. In this paper the clinical observations with special reference to agalactia post partum are presented.

\section{Materials and methods}

\section{Anımals}

A total of 39 pairs of full sibs (Swedish Landrace $\times$ Swedish Yorkshire) were used in the experiment, approximately $2 / 3$ of them entering as gilts. Each sow was if possible kept for 6 parities. One sib was allocated to the control group, the other to the experimental group.

The gilts were mated at their second oestrus using a Swedish Yorkshire boar and the same boar was in most cases used for each sib pair. Three weeks before expected farrowing the sows were transferred to the farrowing pens. Weaning was carried out when the piglets were 6 weeks old. At weaning the sows were moved to stalls next to the boar for mating and the piglets were kept in the farrowing pens for another 3 weeks. After mating sows were kept in pens in groups of 4 but were individually fed. Data concerning performance and reproduction were collected.

\section{Feeding}

All sows were fed a commercial type of diet (Table 1) and had free access to straw and 
Table 1. Composition of the feed mixture used in the experiment.

\begin{tabular}{lc}
\hline Composition: & $\%$ \\
\hline Barley & 59.1 \\
Oats & 20.0 \\
Wheat bran & 5.0 \\
Lucerne meal & 5.0 \\
Soy bean meal & 4.0 \\
Fishmeal & 2.0 \\
Meat meal & 2.0 \\
Minerals ans vitamins & 1.9 \\
\hline Chemical composition: & \\
\hline & \\
ME, MJ/kg & 11.5 \\
Crude protein \% & 14.9 \\
Digestible crude protein, $\mathrm{g} / \mathrm{kg}$ & 115 \\
Crude fibre, \% & 5.8 \\
Ca, \% & 0.82 \\
P, \% & 0.60 \\
\hline
\end{tabular}

water. The total amount of feed given during the gestation period was the same for both groups. The animals in the control group (C) were fed $2.4 \mathrm{~kg}$ per day the first 100 days of pregnancy and then $3.4 \mathrm{~kg}$ day until farrowing. The experimental group (E) was offered extra feed between 30-100 days of gestation and then fed $1.0 \mathrm{~kg}$ daily (minerals and vitamins supplemented) during the last 15 days of gestation. During lactation the daily feed allowance was increased to a maximum of $4.0 \mathrm{~kg}+0.2 \mathrm{~kg}$ per piglet within 14 days after farrowing.

\section{Experimental design}

The rectal temperature was monitored twice a day, morning and evening, starting 2 days before expected farrowing and continuing until 2 days after farrowing to detect diseased sows as early as possible. When a sow had a temperature exceeding $39.5^{\circ} \mathrm{C}$ within the first $48 \mathrm{~h}$ after farrowing an examination was performed immediately by a veterinarian.
The general condition and temperament of the sow, appetite and thirst were recorded and the external genital organs were inspected. Milk samples were collected from at least 4 different glands of each sow after careful disinfection. Preferably glands with signs of inflammation were sampled together with normal glands opposite to the affected ones. After sampling the sows were treated parenterally with oxytocin and broad-spectrum antibiotics. Severely affected animals were also treated with corticosteroids. The treatment with antibiotıcs was continued for another 2 days. A follow-up clinical examination including collection of milk from the same glands was done 2 days later. Milk sampling was then repeated 7 and 21 days after the sow was first diagnosed as being ill. Sows not showing symptoms of agalactia were milk sampled as healthy controls but in these cases no clinical examinations were performed. Milk samples were collected during altogether 78 lactations of agalactic sows and 96 lactations of healthy sows. The sampling technique and results from milk analysis will be presented in a separate paper (Pedersen et al. in prep.).

\section{Statıstical methods}

Statistical evaluation was performed using procedures available from the Statistical Analysis System (SAS 1982:. Frequency distribution was established using PROC FREQ, where significance was determined by the chi-square test. The analysis includes: agalactia incidence, recurrence rate of agalactia, some clinical observations, agalactia occurrence in subsequent parities. Analysis of variance was carried out according to the GLM procedure. The following model was used for rectal temperature measurements, length of gestation, litter size at birth and weaning, and interval to the first oestrus: 


$$
\begin{array}{cl}
y_{1 \mathrm{jk}}=\mu+a_{1}+b_{\mathrm{j}} & +(a b)_{1 \mathrm{j}}+e_{\mathrm{j} \mathrm{k}} \\
\text { where } \quad y_{1 \mathrm{jk}} & =\text { the } \mathrm{i} \ldots \text { th observation } \\
\mu & =\text { general mean } \\
a_{1} & =\text { effect of group }(E, C) \\
b_{\mathrm{j}} & =\text { effect of agalactia } \\
(\mathrm{ab})_{\mathrm{j}} & =\text { interaction effect } \\
e_{\mathrm{j} \mathrm{jk}} & =\text { error term }
\end{array}
$$

\section{Results}

The investigation comprised 376 lactations. In the experimental group, the sows developed agalactia in 26 out of 181 lactations and in the control group, in 52 out of 195 lactations $(0.01>\mathrm{p}>0.001)$. The age distribution (parity number) of agalactic and healthy sows, milk sampled or not respectively, is presented in Fig. 1.

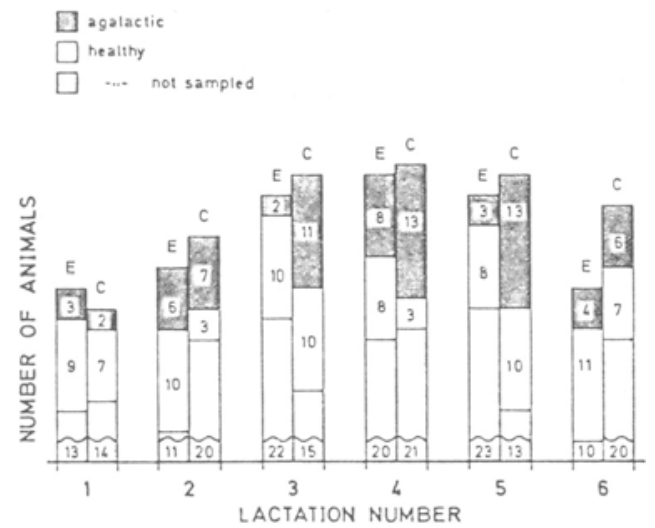

Figure 1. Number of animals included in the trial. One bar for the experımental (E) and one bar for the control (C) group respectively represent each lactation number. Each bar is divided into three separate parts, which denote agalactıc, healthy and healthy but not sampled sows.

The recurrence rates of agalactia among the two groups of sows ( $\mathrm{E}$ and $\mathrm{C}$ respectively: are presented in Table 2. After exclusion of all lactations of sows diseased at 3 or more lactations the incidence of agalactia decreased from $26.6 \%$ to $19.4 \%$ in the control group and from $14.4 \%$ to $9.7 \%$ in the experimental group. The rectal temperatures of
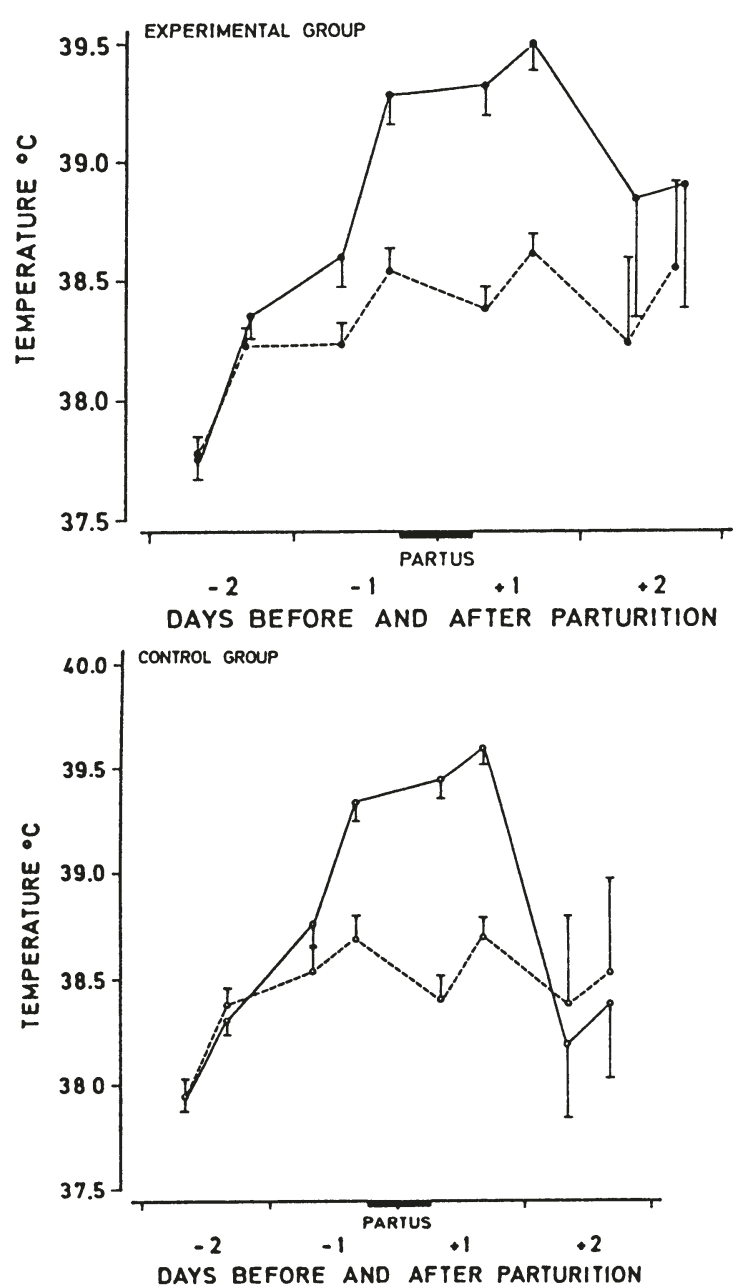

Figure $2 \mathrm{a}$ and $2 \mathrm{~b}$. Rectal temperatures of periparturient sows belonging to experimental $(-\rightarrow)$ and control group $(\mathrm{O} \mathrm{O})$ respectively. The upper lines in both figures illustrate the elevated rectal temperature in sows which developed agalactia post partum, while the lower lines illustrate the rectal temperature of apparently healthy sows. Horizontal black bar denotes time of parturition.

the affected and healthy sows are presented in Figs. 2a and b. The mean temperature was significantly higher in the affected sows from 1 day before farrowing until 1 day after 
Table 2. Occurrence of agalactia.

\begin{tabular}{lcccc}
\hline Group & $\begin{array}{c}\text { Number of anımals } \\
\text { never diseased durıng } \\
\text { the experimental period }\end{array}$ & $\begin{array}{c}\text { Number of anımals } \\
\text { diseased at } \\
\text { 1 lactation }\end{array}$ & $\begin{array}{c}\text { Number of anımals } \\
\text { diseased at } \\
\text { 2 lactations }\end{array}$ & $\begin{array}{c}\text { Number of animals } \\
\text { diseased at more } \\
\text { than 2 lactations }\end{array}$ \\
\hline Experimental & 24 & 9 & 3 & 3 \\
Control & 11 & 13 & 9 & 6 \\
\hline
\end{tabular}

farrowing. No differences were found between control and experimental animals within the diseased and healthy groups, respectively.

Results concerning the general condition and feed and water consumption in the diseased sows are given in Table 3. A majority of the sows in the control group were clinically affected at first examination whereas on the same occasion the majority of experimental animals were registered as unaffected. At the second examination most of the animals were normal in both groups. In $46.2 \%$ of agalactic sows in the control

Table 3. Clinical observations in agalactic sows.

\begin{tabular}{|c|c|c|c|c|}
\hline \multirow{2}{*}{$\begin{array}{l}\text { General } \\
\text { condition }\end{array}$} & \multicolumn{2}{|c|}{ Experımental group $n=26$} & \multicolumn{2}{|c|}{ Control group $=52$} \\
\hline & 1st examınat & 2nd examınat & 1st examınat & 2nd examinat \\
\hline Unaffected & 16 & 19 & 15 & 33 \\
\hline Irritated & 2 & 3 & 9 & 5 \\
\hline Depressed & 6 & 2 & 23 & 4 \\
\hline Apathetic & 1 & 0 & 2 & 0 \\
\hline $\begin{array}{l}\text { Information } \\
\text { not available }\end{array}$ & 1 & 2 & 3 & 10 \\
\hline \multicolumn{5}{|c|}{ Feed consumption } \\
\hline Normal & 20 & 24 & 24 & 39 \\
\hline Low & 3 & 0 & 11 & 3 \\
\hline None & 2 & 0 & 13 & 0 \\
\hline $\begin{array}{l}\text { Information } \\
\text { not available }\end{array}$ & 1 & 2 & 4 & 10 \\
\hline \multicolumn{5}{|c|}{ Water consumption } \\
\hline Normal & 21 & 24 & 24 & 40 \\
\hline Low & 2 & 0 & 11 & 2 \\
\hline None & 2 & 0 & 13 & 0 \\
\hline $\begin{array}{l}\text { Information } \\
\text { not avallable }\end{array}$ & 1 & 2 & 4 & 10 \\
\hline Clinical udder & & & & \\
\hline
\end{tabular}

Number of lactations with udder changes observed as reddenıng and/or swelling and or soreness 23 15 38 16 
group, the consumption of water and feed was reduced or completely ceased at the first examination. The corresponding figure in the experimental group was $15.4 \%$. The results from the clinical examinations of the udders of the agalactic sows are given in Table 3. Udder changes were recorded in $88 \%$ of the lactations in the experimental group and in $73 \%$ in the control group on the first examination and in 58 and $31 \%$ respectively on the second examination. One of the agalactic sows in the control group showing udder changes had developed severe symptoms of circulation failure at the first examination.

In 10 of 26 farrowings in the experimental group and in 19 of 52 farrowings in the control group vaginal discharge was observed at one or both of the clinical examinations. In only 2 agalactic lactations were symptoms of clinical metritis observed.

No differences were seen in incidence of agalactia for the different parities (Table 4).

Table 4. Distribution of agalactia according to parity (number of animals). Only animals entering the experiment as gilts are included.

\begin{tabular}{lrrrrrr}
\hline & \multicolumn{6}{c}{ Parity } \\
\cline { 2 - 7 } Sows & 1 & 2 & 3 & 4 & 5 & 6 \\
\hline Healthy & 44 & 36 & 39 & 32 & 31 & 29 \\
Agalactic & 5 & 10 & 7 & 13 & 13 & 7 \\
\hline
\end{tabular}

Data of length of gestation periods and oestrus are given in Table 5. No effect of the length of the gestation period on agalactia was registered. Neither were differences found in the interval from weaning to first oestrus for healthy and agalactic animals respectively. No differences in litter size at birth or at weaning were found between agalactic and non-agalactic sows (Table 6). However, agalactic sows farrowed a significantly higher number of stillborn piglets compared to non-agalactic sows (Table 6).

Twenty-six of 39 sows in the experimental group and 32 of 39 sows in the control group remained in the trial throughout the designated 6 lactations. Due to reproductive disturbances, e. g. abortion or failure to hold to service, 5 sows in the experimental group and 2 sows in control group were slaughtered during the experiment. Five animals in the experimental group and 2 animals in the

Table 5. Length of gestation and interval from weaning to first oestrus (days). Mean \pm s.e.m.

\begin{tabular}{lcc}
\hline Sows & Gestation length & $\begin{array}{c}\text { Weaning to first } \\
\text { oestrus }\end{array}$ \\
\hline Agalactic & $\begin{array}{c}115.1 \pm 0.2^{\mathrm{a}} \\
(\mathrm{n}=77)\end{array}$ & $\begin{array}{c}6.9 \pm 0.7^{\mathrm{b}} \\
(\mathrm{n}=74)\end{array}$ \\
Non agalactic & $\begin{array}{c}115.0 \pm 0.2^{\mathrm{a}} \\
(\mathrm{n}=92)\end{array}$ & $\begin{array}{c}6.4 \pm 0.6^{\mathrm{b}} \\
(\mathrm{n}=85)\end{array}$ \\
\hline
\end{tabular}

a, b Means within columns with the same superscript are not significantly different $(p>0.05)$.

Table 6. Litter size at birth and at weaning. Mean \pm s.e.m.

\begin{tabular}{lccc} 
& \multicolumn{2}{c}{ Litter size } \\
\cline { 2 - 4 } & \multicolumn{2}{c}{ at birth } & at weaning \\
\cline { 2 - 4 } Sows & born alıve & stillborn & \\
\hline Agalactic & $11.4 \pm 0.3^{\mathrm{a}}(\mathrm{n}=71)$ & $1.0 \pm 0.1^{\mathrm{a}}(\mathrm{n}=76)$ & $9.1 \pm 0.3^{\mathrm{a}}(\mathrm{n}=76)$ \\
Non agalactic & $12.2 \pm 0.3^{\mathrm{a}}(\mathrm{n}=93)$ & $0.6 \pm 0.1^{\mathrm{b}}(\mathrm{n}=93)$ & $9.6 \pm 0.3^{\mathrm{a}}(\mathrm{n}=93)$ \\
\hline
\end{tabular}

$a$, b Means within columns with different superscripts are significantly different $(p<0.001)$. All other within column means are not significantly different $(p>0.05)$. 
control group were slaughtered due to acute disease, such as sudden paralysis or bone fractures. One animal in the experimental group and 2 animals in the control group were culled due to chronic lameness caused by arthritis and abscesses. The cause of culling was not recorded for 3 animals. Most of the remaining sows could be used for other experimental purposes.

\section{Discussion}

When comparing the results from the present experimental study with results obtained from earlier field studies it must be emphasized that this was a long-term study at an experimental station where a number of sows were followed through 6 lactations. The incidence rates of agalactia in the present study were high, $14.4 \%$ and $26.6 \%$ in the experimental and control groups, respectively which might be due to the very careful observation of the sows allowing detection also of mild cases of agalactia post partum (see Introduction). The early diagnosis of agalactia in the present study is also demonstrated when comparing general condition as well as water and feed consumption of agalactic sows with the results of Hermansson (1978) and Ringarp (1960), as the sows in our study were found to be less clinically affected.

Recurrence rates of agalactia in this study are in agreement with earlier observations (Hermansson et al. 1978, Jorsal 1983). No significant effect of parity number on agalactia could be observed in contrast to the results of Jorsal (1983), who found that first parity sows were significantly more often agalactic and that incidence rates decreased with an increasing farrowing number. These conflicting results might be due to the different designs of the trials. In the present study the same sows were followed during 6 consecutive lactations.
A prefarrowing increase in the rectal temperatures was registrered in all sows in this study. Significant differences were seen in body temperatures between agalactic and healthy animals already 1 day before expected farrowing. No differences however were obtained between control and experimental animals. Using radiotelemetry Elmore \& Martin (1979) continuously monitored rectal temperatures in clinically healthy sows from 1 week before expected farrowing till 3 weeks after farrowing. The mean prefarrowing value was $38.3^{\circ} \mathrm{C}$ and the temperature began to increase at a mean of $13 \mathrm{~h}$ prior to the delivery of the first piglet. During the whole lactation period the temperature varied between $38.9^{\circ} \mathrm{C}$ and $39.5^{\circ} \mathrm{C}$. Within 24 $\mathrm{h}$ after weaning the temperature returned to the prefarrowing level. The significantly higher rectal temperatures in agalactic sows in the present study indicate an early establishment of the disease.

The mechanisms behind the influence of reduced feeding on agalactia have been discussed in earlier reports. In our trial the group given a restricted feed allowance had a significantly lower incidence of agalactia. Results from registrations regarding general condition, thirst and appetite in diseased sows also indicate that the control animals were more affected than animals in the experimental group. These results suggest an impact of feeding intensity not only on incidence but also on severity of agalactia. Ringarp (1960) proposed that bacterial toxin production in the intestinal tract could be of etiological importance and Sandstedt \& Sjögren (1982) proposed that reduced feeding could impair the conditions for toxin production in the gut. Gooneratne et al. (1982) found an altered composition of colostrum from sows which subsequently developed agalactia and suggested that the premature initiation of lactation resulting in an en- 
gorgement of the mammary gland predisposes the sow to agalactia. The intensity of feeding might in the present study have affected the initiation of lactation and/or the udder engorgement in connection with parturition, resulting in an impaired susceptibility to udder infections. These factors however must be further elucidated. Udder changes were registered in $88.4 \%$ of agalactic sows in the experimental group and in $73.1 \%$ of agalactic sows in the control group. These results are in accordance with the work of Ringarp (1960), but higher than in the work of Hermansson (1978), who reported signs of mastitis in $45-52 \%$ of agalactic sows. The differences in percentages of agalactic sows with udder changes between groups $\mathrm{C}$ and $\mathrm{E}$ in the present study might indicate an influence of feeding intensity. The results from bacteriological and cytological examinations of milk from affected and nonaffected sows will be presented separately (Pedersen et al. in prep.). However, it should be mentioned that in more than $80 \%$ of the agalactic lactations in both groups significant levels of bacteria were found in the milk from one or more mammary glands.

In 29 of 78 farrowings in the present study vaginal discharge was observed at one or both clinical examinations. However, only 2 were diagnosed as cases of metritis. Hermansson (1978) after careful inspection found the presence of a vaginal discharge in $97 \%$ of affected sows and $88 \%$ of normal sows. During recent years it has been shown by histopathology and bacteriology that metritis is not a consistent component of the agalactia syndrome (Ross et al. 1981, Middleton-Willams et al. 1977). However, in some herds metritis occurring within the first days after farrowing could be a problem.

In the current study no effects of the length of the gestation period on the occurrence of agalactia were found. Neither was agalactia shown to influence the interval from weaning to first oestrus. These results agree well with the results of Hermansson (1978) and Jorsal (1983). In our material no differences were seen between healthy and agalactic sows regarding total number of piglets born. Sows developing agalactia farrowed more stillborn piglets than healthy sows. These results indicate an early effect of the post partum agalactia syndrome during late pregnancy and/or in labour. This is also supported by the previously described rise in rectal temperatures before parturition.

\section{Acknowledgements}

This work was supported by grants from the Swedish Council for Forestry and Agriculture Research and from the Swedish Unıversity of Agricultural Sciences.

Professor Stig Einarsson and Professor Ingmar Månsson are gratefully thanked for valuable discussions. The authors are indebted to Miss Catharina Falkenberg for excellent technical assistance, Dr. Brian Ogle for valuable comments on the manuscript and Miss Carina Bohlin for skillful typing of the manuscript.

\section{References}

Backstrom L: Environment and animal health in piglet production. A field study of incidence and correlations. Acta vet. scand. suppl. 41, 1973.

Bäckström L, Elnarsson S, Gustafsson B, Larsson $K \cdot$ Prostaglandin $F_{2}$ alpha induced parturition for prevention of the agalactia syndrome in the sow. Proceed. 4th. Inter. Pig. Vet. Soc. Cong. Ames, Iowa, USA 1976, E. 5.

Einarsson S, Gustafsson B, Larsson $K$ Prostaglandin induced parturition in swine with some aspects on prevention of the MMA (mastitis, metritis, agalactia) syndrome. Nord. Vet.-Med. 1975, 27, 429-436.

Elmore RC, Martın CE, Riley JL, Littledike T Body temperature of farrowing Swine. J. Amer. Vet. Med. Assoc. 1979, 174. 620-622. 
Elmore $R G$, Martın $C E$ Mammary Glands in Diseases of Swıne. 6th Ed., Iowa University Press, Ames, Iowa, USA 1986.

Gooneratne AD, Hartmann PE, Nottage HM. The initiation of lactation in sows and the mastitis-metritis-agalactia syndrome. Animal Repr. Sci. 1982, 5, 135-140.

Hermansson I, Einarsson S, Larsson K, Bäckström On the agalactia postpartum in the sow, a clınical study. Nord. Vet.-Med. 1978, 30, 474-481.

Jorsal SE Morbiditet hos søer. Epidemiologıske undersøgelser 1 intensive sobesætninger med særligt henblik på farefebersyndromet. (Morbidity in sows). Licentiatafhandling. Institut for intern medicin. Den Kgl. Veterinær- og Landbohøjskole, København, Denmark, 1983.

Middleton-Willams, DM, Pohlenz J, Lott-Stolz $G$, Bertschinger $H U$ Untersuchungen über das Mastitis-Agalaktiae-syndrom der Sau. Patologische Befunde bei Spontanfälle. (Investigations of the mastitis-agalactia syndrome of the sow. Pathological findings in spontaneous cases). Schw. Arch. Tierh. 1977, 119 213-222.

Pedersen $A E$. A long term study on the health status and performance of sows on different feed allowances during late pregnancy 2 . Bacteriology of milk from agalactic and non agalactic sows during the first three weeks of lactation. In preparation.

Rıngarp $N^{\cdot}$ Clinical and experımental investigations into a post parturient syndrome with agalactia in sows. Acta Agr. Scand. Suppl. 7, 1960.

Ross RF, Zimmermann BJ, Wagner WC, Cox $D F$ A field study of coliform mastitis in sows. J. Amer. Vet. Med. Assoc. 1975, 167, 231235.

Ross RF, Orning AP, Woods RD, Zimmerman $B J$, Cox DF, Harris DL: Bacteriologic study of sow agalactia. Amer. J. vet. Res. 1981, 42, 949-955.
Sandstedt $H$, Sjögren $U$, Schwan $O$ Förebyggande åtgärder mot MMA (agalakti) hos sugga. (Preventive measurements against MMA in the sows). Sv. Vet. Tidn. 1979, 7, 193-196.

Sandstedt $H$, Sرögren $U$ : Förebyggande åtgärder vid hög frekvens av MMA i suggbesättningar. (Preventive measurements at a high occurrence of MMA in sow herds). Sv. Vet. Tidn. 1982, 11, 487-490.

SAS User's Gulde. Statistics. Statistical Analysis System Institute Inc., Cary, N. C. 1982.

\section{Sammanfattning}

En långtıdsstudie rörande hälsotıllstånd och produktionsresultat hos suggor på ollka fodergivor under sen dräktıghet

I. Klınıska ıakttagelser med speciell inrıktning på agalaktıa post partum

Effekterna av fodergivans storlek under de sista 15 dräktighetsdagarna på förekomsten av agalakti post partum hos sugga studerades i ett långtidsförsök där 39 systerpar följdes under 6 laktationer. Frekvensen agalakti var signifikant högre bland de djur som erhållit en högre fodergiva under högdräktigheten jämfört med de djur som fătt en kraftigt reducerad fodertilldelning under samma period. Vid den kliniska undersökningen uppvisades majoriteten av agalaktisuggorna förändringar $i$ juvret. Insjuknade suggor visades redan från en dag före grisning ha en signifikant högre rektaltemperatur än de djur som inte drabbades av agalaktı post partum. De djur som insjuknade fick dessutom ett signifikant högre antal dödfödda grisar. Dessa observationer indikerar att sjukdomen var etablerad redan före grisningen. Inget samband sågs mellan dräktighetstidens längd eller suggans ålder och förekomsten av agalakti. Reproduktionen observerad som intervallet från avvänjning till första brunst påverkades inte av att suggan haft agalakti under den föregående laktationen.

(Accepted May 24, 1988).

Reprints may be requested from: Arne Persson, Dept. of Obstetrics and Gynaecology, Swedish University of Agricultural Sciences, P. O. Box 7039, S-750 07 Uppsala, Sweden. 
